\title{
Desenvolvimento Nacional e Fortalecimento do Potencial
}

\author{
Prof. José de Almeida Rios
}

\section{INTRODUÇÃO}

A

o findar-se o longo periodo feudal e começar a influência decisiva da era tecnológica com a intensificação da urbanização, várias modificações sofreu o processo de evolução social. A primeira alteração foi o aumento progressivo da população mundial. A segunda, foi a organização dos grupos profissionais de trabalho concomitante com a intensificação da urbanização. A terceira, foi a queda das oligarquias feudais e nobres provocada justamente pela nova classe que se tornava mais forte pelas duas condições inicialmente enunciadas: a classe burguesa. O quarto acontecimento foram as descobertas geográficas, diversificando as matérias-primas, incorporando novos povos e aumento conseqüente da capacidade consumidora. Em quinto lugar verificou-se a expansão de consumo de produtos e bens apenas destinados até então a uma minoria privilegiada. Vigoraram durante muito tempo as regalias a favor de certa classe social e que continuaram a existir sob a forma de uma segregação política e social. Com a queda das oligarquias que se utilizavam do Poder para manter suas regalias e vantagens, começou o povo a sentir que, realmente, de sua decisão dependiam muitas das formas e fontes do Poder Politico, justamente o que dominava a favor de um grupo as vantagens e os privilégios, inclusive, no processo educacional e cultural. A antiga tradição de considerar governantes os delegados da divindade, quando se sujeitava o povo a pasmar-se a deslumbrar-se com a maior pompa possivel que ostentassem na sua vida e no seu circulo, desmoronou-se lentamente. Não foi estranho a isso a vinda do Cristianismo que demonstrava a encarnação "humana" do próprio Deus. Assim, sentiu-se dentro do homem a consciência de uma sublimidade até então desconhecida. Com a expansão do consumo foi necessário haver maior esmêro e rapidez na fabricação, para o que se encetaram experiências e aperfeiçoamentos dos meios técnicos já existentes. Durante milênios for 
ram-se acumulando as experiências mecânicas na tendência humana natural do menor esfôrço muscular. Como bem assinalou Nober Wiener, cada instrumento tem a sua genealogia, pois que se originou da ferramenta de uso corrente. Iniciado o espirito tecnológico, passando por uma era tecnológica, o Estado Liberal que sucedeu vitoriosamente aos governos oligárquicos autoritários como uma ação vigorosa da burguesia dos séculos XVII, XVIII e do inicio dêste, criou a Tecnologia. Foi realmente a grande conquista da economia liberal na sua curta passagem pela História. Foi a mola mestra da expansão econômica e da satisfação razoável das reivindicações populares partidas dos grupos profissionais organizados. Assim pois, bastava antigamente um simples artezanato para atender a uma clientela privilegiada. Com a aceleração da dinâm ca social, aumento populacional, interpenetração de classes, estimulo a trocas comerciais, aperfeiçoamento das técnicas de comunicações e de transportes, conseguiu-se a expansão de mercados ávidos de gozar os bens e serviços colocados à dispos:ção de todos. Sendo aumentada a produtividade, começaram os trabalhadores a captar maior cota do produto da riqueza disponível. Êles mesmos ampliaram o campo de consumidores. As pesquisas e estudos demonstraram que no presente século a produtividade, isto é, a Ciência, a Técnica e a Organização contribuiram com 50 a $70 \%$ da formação do produto final, deixando ao capital e ao trabalho, em conjunto, a responsabilidade do restante. Já havia condições para que a Economia pudesse realmente ser encarada em benefício de todos, bastando para isto que o Estado tomasse novas decisões e se reestruturasse de acôrdo com a nova condição surgida na sistemática da evolução social. Como sempre, a Tecnologia, seguindo a própria filosofia da persistência da vida humana no planeta, exige a renovação, a inovação e a transformação, fundamentos da Evolução, com o que, ela, como o Homem, deve sémpre criar novos problemas e preparar-se para resolvê-los. Retirando-se aos homens a iniciativa individual, a liberdade de discutir e debater suas idéias e pensamentos, tenta-se, aliás improficuamente, em nivelar a Cultura. A satisfação completa, a ausência de luta, a segurança absoluta, a assistência social deformada, fogem ao sentido biológico da própria vida. Totalmente mecanizada a vida do homem, na ordem material, na categoria espiritual, na sentimental e na implantação da perfeição iremos verificar tremendas deformações compensadoras e tendentes à destruição da Humanidade. A volta à barbaria seria uma das alternativas. Eis porque, tôdas as pretendidas filosofia decorrentes visando estrangular a iniciativa c não controlá-la simplesmente, são falsas em sua essência e inautênticas em sua doutrina. Tôdas 
as experiências extremas que politicamente tentam "padronizar e mecanizar" a vida humana não estão construindo realmente um progresso no plano da Evolução senão apenas um progresso no plano do Desenvolvimento. Êste estancará ao ter que atender a expansão imensa da demografia mundial sem possuir contudo a inovação, a modificação, a transformação e a renovação, fundamentos da Evolução. Daí decorreu, pois, a grande transformação política da Democracia Social e, muitas vêzes, da formação do próprio Estado Bem-Estar, onde, sem extremistas, deixa ao indivíduo as iniciativas, controla, disciplina, fiscaliza e aproveita os fatôres negativos biológicos irredutiveis do gênero humano, drenando tais impulsos em benefício social. O aumento da riqueza coletiva é indispensável; a sugestão para o cumprimento do dever de trabalhar deve seguir-se àquela determinação da sociedade de humanizar o trabalho. Ao esfôrço coletivo deve-se retribuir com a mais ampla distribuição da riqueza resultante. A todos deverão ser proporcionadas oportunidades iguais ao se propiciar condições suficientes de estimulo para que na iniciativa própria o indivíduo lute para a posição e situação que julgue justa da sua capacitação, de seu valor e de sua parcela de contribuição ao bem-estar social. Sòmente $\mathrm{com}$ tais propósitos deve um Estado procurar intensamento o Desenvolvimento. Contudo, como na Humanidade seja impossivel uma uniformidade cultural, contrária inclusive ao sentido mesmo da Evolução, mister se faz conseguir, paralelamente à criação e acumulação de riquezas materiais e espirituais, o sentido de garantia. No mundo econômico de hoje em que a arma específica é a Tecnologia, dela devemos lançar mão para conciliar os objetivos e finalidade de Desenvolvimento com as determinações de Segurança. Sòmente um forte Poder Nacional será capaz de dispensar à Política os argumentos convincentes de garantia. A história do passado en "conseguir" riquezas acumuladas por outros povos, repete-se sempre, mas, toma novas características. A Técnica é diversa, as ações são variadas, os métodos mais refinados, o esfôrço e o desgaste são poupados e as artimanhas se conjugam ora ideolo. gias falsas e utopias enganadoras ora com atos violentos sem guerra declarada. A Politica é a continuação da guerra por outros meios, disse Clausewitz.

Assim, vamos tratar do assunto de Desenvolvimento e do fortalecimento do Potencial Nacional, resguardando os princípios fundamentais da filosofia democrática de vida. Esta atinge e interessa as Nações em suas relações entre si, os Estados e os cidadãos e as comunicações que firmam a vida social. Não cons- 
titui reg 'me, nem forma, nem sistema de govêrno. E' uma conceituação moral a que se obrigam os entes humanos exaltando o espírito de solidariedade como fundamento conclusivo da própria forma de viver dos povos. Nenhuma Nação conseguiu desenvolver-se e evoluir sem a ajuda de outras Nações. Não existe economia introvertida. No caráter e na atitude que ainda regem os grupos humanos na mística de uma nacionalidade que despontou justamente quando se delimitaram as aspirações, os interêsses e os objetivos de grupos sociais integrantes em sentimentos sincrônicos, desejos semelhantes, coesos pelas mesmas tradições históricas e irmanados pelo caráter, hábitos de vida e de sentir, harmonizados em uma constância pertinaz de fatos e acontecimentos repetidos pelos anos a fora. Decorre, pois, que uma moti. vação importante congrega esforços, soma recursos e solidariza nos riscos para cumprirem juntos os destinos de cada qual sem que sejam afetados seus deveres para com a Humanidade. Ao visarmos a valorização do gênero humano, na vida material, espiritual e sentimental, devemos outrossim integrá-lo na sociedade universal, enfatizando com vigor a solidariedade, supremo alvo a ser atingido. Nunca, até hoje, qualquer nacionalidade pôde eximir-se de depender de outra na sua faina de produzir e conservar riqueza e bem-estar. Nenhum território conseguiu na industrialização adiantada tôda a gama de matérias-primas de que necessita como potencial aproveitável de seu subsolo. Aquelas que surgiram como grandes Nações só consegu ram tais situações pela oportunidade que lhes proporcionou as fases históricas do emprêgo da fôrça ou do emprêgo desigual dos postulados da economia liberal onde recursos tecnológicos foram utilizados para acumular riquezas, objetivo fundamental da economia. Poder gera Poder, riqueza gera riqueza. E' preciso contudo que, dentro da filosofia da vida democrática, a Economia seja hoje o meio para distribuir ao maior número, senão a todos, o produtos da formação de bens e serviços.

Existe um mínimo contudo que não pode ser desviado do consumo, dado que é suficiente apenas para atender aos requ'sitos indispensáveis de vivência condigna dentro dos postulados universalmente aceitos de dignificação da pessoa humana. Contudo, outros povos deverão acorrer, autentificados com a filosofia democrática de vida, proporcionando oportunidades para que seja coroado de êxito o esforço coletivo visando e perseguindo a criação de riquezas para todos.

E' dentro destas idéias que passamos a tratar do Desenvolvimento e do Fortalecimento do Potencial Nacional. 


\section{0 - DESENVOLVIMENTO E POLÍTICA}

1.1 - Desenvolvimento econômico e influência politico-partidária.

Desenvolvimento econômico é o aumento da produtividade física do conjunto da fôrça de trabalho de uma economia, sendo êste aumento de produtividade obtido mediante uma expansão da capacidade produtiva maior que o crescimento da fôrça de trabalho.

O ritmo de crescimento de uma econom:a inteiramente livre, não sujeita a contrôles, inclusive de trustes e poderosos monopólios, tem sempre um limite. Na necessidades imperiosa de um govêrno atender a empreendimentos de caráter econômico, não sem antes ser verificada a causa dos retraimentos da iniciativa privada, impõe a técnica de Planejamento. Serão, assim, corrigidos as distorções e os desequilibrios previsiveis atinentes à flexibilidade do cercado, frente a maiores ou menores somas de captações é de inversões de capitais, provocando, inclusive a retração do mercado consum dor. Para acelerar o crescimento é preciso aumentar as inversões, com $o$ que se pode reduzir o consumo, caso os capitais não tenham origem estrangeira. A redução de consumo resulta, pois, em uma redução do ritmo de crescimento. Se reduzirmos o consumo visando aumentar a capitalização e aguarda um maior consumo futuro, poderiamos prevocar crise de desemprêgo e redução do consumo. O Planejamento, pois, procura obter taxa máxima de crescimento adequada à estrutura econômica considerada, provendo e preverdo tôdas as conseqüências futuras das ações indispensáveis à captação de capitais e à seleção dos investimentos. A determinação da taxa, no Planejamento, é de especial importância para que as medidas corretivas tenham eficácia na suportável alteração ou conseqüências a serem sofridas. Por outro lado, a plena ocupação da sociedade de instalações e mão-de-obra já utilizadas permitirá maior disponibilidade de inversão prioritária. A consideração dos prazos, de rentabilidade, da essenciabilidade e da oportunidade dos investimentos mostra o jôgo eficaz dos fatôres disponíveis sòmente aproveitáveis com o Planejamento.

Arthur Lewis em sua obra Planejamento Economico aponta como primeira etapa para o "Planejamento Econômico" a "estrutura de renda nacional em pleno emprêgo", a relação com o mecanismo das demandas e com as despesas públicas. Após isto, seguem-se os planos para atuar as ocorrências de escassez e conseguir meios de incrementar a oferta e, enfim, o cálculo para equilibrar tais ações.

O Desenvolvimento Nacional é o objetivo que leva o Estado a encetar uma ação coordenada, sinérgica, proporcionada, racio- 
nalizada e equacionada frente aos problemas para conseguir cada vez maior bem-estar para a coletividade, aumentar o Poder $\mathrm{Na}$ cional e ampliar concomitantemente o grau de Segurança. A prosperidade e o aumento do Poder Nacional impõem na fase atual da dinâmica social um perfeito conhecimento de todos os fatôres favoráveis e desfavoráveis que possam facilitar ou dificultar o desenvolvimento da Nação.

Na conceituação de Poder nunca poderemos deixar de raciocinar dentro da relatividade. Necessita a Nação de Poder e cada vez mais Poder, dada a função de aplicação contra ou para alguma coisa, tanto já determinada nos Objetivos Nacionais Permanentes como os antagonismos, pressões e obstáculos que se antepuseram na consecução das etapas intermediárias. Por outro lado, estas dificuldades são muitas vêzes imprevisíveis, na natureza e no valor, Nunca um Poder chega a ser suficiente. Necessita êle pois, cada vez, maior valorização de suas expressões, mostrando o imperativo de conseguir constantes transformações e mudanças, inclusive com novas características. Estas mudanças constantes de valores novos a serem acrescidos ao Poder decorrem do Fortalecimento do Po tencial Nacional. As novas expressões demográficas do Poder necessitam de qualificação, melhor distribuição e formação de mãode obra. Os valores já existentes também podem sofrer modificações na sua melhor qualificação. Em tais ações são aplicadas parcelas do Poder. O Poder, pois, gera sempre Poder.

Com $D$ exposto vemos a necessidade de aplicar os recursos frios da Tecnologia, ordenados, coordenados, racionalizados, com ações seletivas, hierarquizadas, prioritárias e determinantes, visando aproveitar ao máximo os recursos e meios disponíveis.

Com países já evoluídos a par de satisfatório desenvolvimento, a ética política contém a atividade politico-partidária e atendem ao clamor dos Estadistas que sempre encontram condições de impor determinações técnicas sôbre imposições politicas. Äinda ai, vamos encontrar a uniformidade de pontos-de-vista técnicos entre os elementos de poder politico, onde uma assessoria récnica influi nas comissões legislativas, levando ao Plenário os elementos decisivos da politica técnica.

No caso dos três podêres independentes e harmônicos, a assessoria técnica está localizada na esfera do poder executivo.

Eis porque ressaltamos a importância da moral dos lideres e das elites inculcando ao povo um sentimento de confiança e de decisão, provocando uma consciente atitude de lutar por um objetivo definido qual seja aquêle do Desenvolvimento. Esta confiança é importante para que o povo dispense a liberdade a seus dirigentes de escolherem os recursos da Tecnologia a serviço 
do Planejamento fugindo de assumir responsabilidade de opinar politicamente na escolha do caminho pretensamente acertado.

E' indiscutivel, por outro lado, a posição de dependência do sistema financeiro sôbre o econôm:co. O primeiro deve, por sto mesmo, tomar a fórmula dogmática ditatorial técnica. Não pode ficar ao sabor de critérios governamentais e sim de critérios técnicos. Assim, sempre funcionou a dinâmica financeira das Nações que hoje desfrutam invejável nível de Desenvolvimento Econômico.

Outro ponto importante de sucesso é a formalistica institucional rigida da Administração Pública, fugindo inteiramente de atender a influências grupais, individuais e personalistas. A própria atividade funcional deve ter garantias especiais que lhe sejam outorgadas pela institucionalização, se não, por uma forma juridica especifica. Sob o manto de tal estrutura será possivel conseguir estabelecer o equacionamento vitorioso de uma Politica de desenvolvimento. Outro setor em que pode sustentar uma sólida política de desenvolvimento é quanto à aplicação dos recursos técnicos. Na análise e na crítica conjuntural selecsionam-se os pontos carentes de uma especial pesquisa cientifica e técnica. A uma Comissão de alto nivel será destinada a incumbência de estabelecer a politica nacional de pesquisas. O Professor RoBert Solow enfatizando a importância do fator técnico-organização disse o seguinte:

"Se a formação de capital nos Estados Unidos se limitasse à produção de maquinaria, equipamentos e métodos conhecidos, o incremento do produto "per capita" declinaria provàvelmente a quase zero, em duas décadas".

No primeiro número da revista do Banco Nacional do Desenvolvimento Econômico encontramos as seguintes palavras do economista José Pelúcio Ferreira, ao mostrar a responsabilidade do setor público nos países com desenvolvimento retardado:

"O Setor Público como responsável pela elaboração do programa e pela coordenação da sua execução, além da contribuição que deve dar diretamente para sua materialização, deverá, evidentemente, aparelhar-se para exercer, com eficiência, essas funções. A capacitação do Setor Público para a condução do programa de desenvolvimento econômico pode desdobrar-se nos seguintes conjuntos de providências:

1. criação ou organização de um sistema nacional de planejamento que permita ao govêrno utilizar coordenadamente os seus vários instrumentos 
- politica orçamentária, política tributária, política cambial, política monetária, política salarial etc. subordinando-os às diretrizes do plano, bem como a conquistar o concurso do setor privado para o cumprimento do programa, no que lhe disser respeito;

2. modernização da máquina administrativa, dando-lhe condições para a execução eficiente de programas de pré-investimentos básicos e de investimentos na ampliação da infra-estrutura econômica do país;

3. aperfeiçoamento constante das instituições econômicas e sociais ajustando-as ao funcionamento de uma sociedade essencialmente dinâmica, como "soem" ser as sociedades dos paises de economia madura -- permeáveis ao processo e às transformações estruturais que traz em seu bôjo.

Como vimos é da maior importância a ação do govêrno, a atitude dos homens públicos merecendo confiança popular e a participação do povo na determinação de contribuit para o desenvolvimento.

\section{0 - DESENVOLVIMENTO E EVOI.UÇão}

Existe e perdura sempre certo grau de desiquilibrio entre desenvolvimento e evolução. $\mathrm{E}^{\prime}$ possivel, inclusive, conseguir um indice de desenvolvimento aceitável sem que o processo de evolução o acompanhe em condições satisfatórias. O exemplo encontramos na vida social dos povos de evolução retardada onde os gastos com alimentação são muito mais sensíveis do que naqueles com maior indice de evolução social. Poderemos conseguir dar bancas escolares para todos desde que racionalizemos com três turnos as instalações existentes. Conseguiremos, assim, desenvolver o ensino escolar. Mas, como os fundamentos da educação escolar é informar e formar, só tornaremos autêntico êste último ao conseguirmos a permanência e o contato mais demorado do aluno com a escola e com seu mestre. Ao elevarmos os salários de certas classes profissionais, ainda pouco evoluidas no sentido da formação, nenhuma melhora de vida higiênica, educacional e social será proporcionada à familia. O dispêndio será dirigido para consumos inadequados, não havendo, inclusive, o sentido de previdência, apanágio dos grupos evoluídos. Por outro lado, a atenção para melhoria das condições técnicas de trabalho, de maior produtividade individual, de interêsses pelos assuntos culturais e disposição de solidarismo social não fazem parte do indivíduo que 
apenas conseguiu "desenvolvimento" para si próprio. E' bem verdade que o têrmo "desenvolvimento" tem sido usado para um processo global e integrado, onde se supõe a evolução como substrato do desenvolvimento. Achamos importante a discriminação dado que verificamos na evolução social dos tempos modernos e, especialmente, a evolução politica, a transformação do Estado moderno tentando formar uma classe média volumosa, sem aguardar o processo de evolução que é muito mais lento. Uma taxa "renda per capita" pode aquilatar do desenvolvimento, mas não atesta o grau de evolução indispensável para considerar-se um país desenvolvido. Há necessidade de verificar, da tecnologia prevalente, o grau de higidez populacional, o nivel educacional escolar, a utilização dos recursos da vida moderna que denotam consumo satisfatório de aço, cimento, energia, etc. Vemos, assim, que os próprios conceitos utilizados nos favorecem na opinião de considerar as duas categorias: evolução e desenvolvimento. Se bem que as duas demonstrem uma interdependência notória, em principio, conjunturas específicas e situações especiais determinam a prioridade de investimentos para o desenvolvimento e uma melhor racionaliza ção dos serviços e instalações miais pròpriamente ligados à evolução.

\section{1 - Consumo e evolução social}

Tem o consumo excepcional importância na determinação do povo ao desenvolvimento. A evolução social, com sua excepcional d'nâmica e novas características trazidas pela técnica de comunicações, modificou essencialmente a estrutura do Estado, levando-o a lançar mão também da técnica para encaminhar bem o seu dever de orientar e disciplinar a economia, visando corrigir as decisões naturais e aquelas artificia:s ligadas a interêsses de grupos, nem sempre atendendo aos reais interêsses da nacionalidade. Como será possivel estabelecer uma política de pesquisas científicas e técnicas visando atender aos reclamos do meio social dos investidores e empresários, se grupos econômicos podem lançar mão de recursos imensos e alterar profundamente as decisões dos consumidores? Esta instabilidade, aumentando os riscos normais dos empreendimentos, poderá deformar a disciplinação planejada para essencialidades fundamentais de uma Politica Nacional inclusive, aquela de Segurança Nacional.

A técnica de propaganda torce o hábito, modifica atitudes, impõe decisões, decide juizos, incide sôbre opiniões, provoca discussões, inova valores, transforma fatôres e pode até modificar o caráter nacional. Não poderia deixar de ter decisiva influência no consumo de bens e serviços, levando a inovações, modificações, transformações e renovações, assim como alterações sensiveis na 
linha de produção e de investimentos. Torna-se, pois, de grande dificuldade seguir uma dogmática doutrinária rígida nos diferentes processos de evolução social.

Eis porque, na formação planificada de uma economia, será necessária a análise cuidadosa e a crítica da conjuntura, assim como prévios e freqüentes exames de situação. Tais análises têm que ser tomadas de modo global e uniforme, classificando antagonismos, pressões e obstáculos, como avaliando as disponibilidades das expressões do Poder, adaptando-se então a um objetivo a ser alcançado. No desdobramento das análises, chegaremos aos setores e agregados os mais periféricos e especializados, para, em uma recomposição, chegarmos aos resultados das análises primitivas e globais.

O processo de desenvolvimento tanto se enquadra intimamente com aquêle de evoluãço social como sofre profundas modificações e alterações específicas, que podem fugir a tôda e qualquer determinação doutrinária clássica. Na economia, então, o fato é incontestável. A conceituação econôm:ca guarda a rigidez de seus postulados como ciência e técnica e sua validez permanece de pé. O que se modificam são os fatôres influenciáveis e imprevisiveís ligados ao procedimento humano.

Contudo, o imprevisto e a surprêsa são a tônica da evolução social do presente século. Nada existe de mais particular a cada pais, região ou zona do que a fisionomia própria de uma conseqüência econômica. A Holanda, grande produtora de manteiga, consome margarina e exporta a sua manteiga. Cada grupo social mundial tem gôsto especial para misturas de café de várias pro cedências. Chamam até pelo nome sugestivo de "bouquet" a tal predileção. Toma-se marcas de café, formando industrialmente sabores próprios. A maior dificuldade na exportação de tecidos é acompanhar as tendências de variados grupos estrangeiros.

Enfim, a técnica de propaganda tem grande influência na programação industrial e na preparação do processo de organização empresarial. Na propaganda política, Jean Meynaud chegou a dizer o seguinte: "A propaganda politica, na época de hoje, não trata sòmente de informar o cidadão, mas sim levá-lo a pensar de certa maneira, de não lhe deixar nenhuma oportunidade de evadir -se do círculo no qual pretende fechá-lo (a violação dos espíritos)".

\section{0 - DESENVOLVIMENTO E INDÚSTRIA}

O Estado através da Politica Nacional deverá ter sempre em vista a perseguição e manutenção dos Objetivos Nacionais Permanentes. Para isto necessita conseguir cada vez maior Poder 
Nacional, aperfeiçoando e valorizando as expressões de poder existente como descobrindo novas fontes aproveitáveis e ainda não consignadas como fatôres ativos de ação. Êste aproveitamento do que existe nada mais é do que o fortalecimento do Potencial efetivo. Outros recursos existem aproveitáveis em futuro imprevisivel conforme as características que possa tomar o processo da evolução social. Na sua Política Nacional deve o Estado conciliar a determinação de desenvolver, com o que consegue cada vez maior grau de bem-estar para a Nação, como, acrescentando novos valores ao Poder Nacional, poderá dispensar a coletividade nacional maior grau de garantia na preservação e satisfação das aspirações e interêsses nacionais, a despeito de antagonismos, pressões e obstáculos de tôda ordem, internos ou externos. Tôda Política $\mathrm{Na}$ cional engloba, pois, a Política de Segurança Nacional.

No desenvolvimento, a par da necessidade de manter um indice de "renda per capita" acima da taxa demográfica de crescimento, de modo a firmar uma acumulação de capital cada vez maior, é preciso ter sempre presente uma estrutura industrial que atenda a uma processo de industrialização variável, flexível e polimorfo, como sirva de fundamento específico para atender a hipóteses graves de controvérsias que possam admitir um conflito armado. Certas atividades são fundamentais e servem de alicerce a outras atividades. No campo da indústria, por exemplo, chamamos as indústrias de base. Estas permitem o aproveitamento direto dos recursos naturais no estado em que são extraídos. Exigem grande quantidade de matérias-primas, assim como, de energia e de transportes. Êstes três grupos, mineração, produção de energia e transportes, são denominados indústrias de infra-estrutura.

Excetuadas estas indústrias de infra-estrutura, as indústrias de base são as que tratam as matérias-primas naturais, conseguindo produtos essenciais das indústrias de transformaçóes. São as seguintes: indústrias químicas, metalúrgicas e mecânicas. Em cada grupo há atividades de base e há indústrias derivadas. Assim, a produção de celulose é uma indústria de base, mas o papel não, as indústrias de ácidos são básicas, mas a pólvora e explosivos já são um ponto acima da escala de classificação; tôda metalurgia de primeira fusão (parte dos minérios e passa pela via liquida) é básica; a fabricação de ligas especiais já não o é (ex. antifricções, ligas leves de alta resistência mecânica ou resistentes à corrosão, aços para ferragens e certos aços especiais); a indústria mecânica de máquinas-ferramentas em geral, de veiculos, de material elétrico leve não são básicas, mas sim, derivadas das indústrias pesadas. As chamadas indústrias-chave, derivadas ou dependentes das de base, são indispensáveis ao desenvolvimento industrial de um país e, especialmente, à produção de meios e 
recursos técnicos de defesa. São elas: a indústria ótica, de aparelhos de medida, a mecânica de precisão, a de veículos de tôda espécie, a de borracha sintética, a de rolamento, a de papel, a de pólvora e explosivos, e de outros produtos intermediários na química orgânica, a de corantes, e de fermentos, etc.

A produção dos três ácidos minerais sulfúrico, azótico e cloridrico é essencial na economia industrial de um país. Um ponto fraco na economia brasileira e mesmo no sentido de Segurança Nacional é a falta de enxofre. Importamos mais 100 t. dos E.U.A., anualmente. E' a matéria prima de fabricação do ácido sulfúrico. A fabricação dos do:s outros ácidos não apresentam problemas intransponiveis. O ácido azótico retirado do ar atmosférico resulta em uma gama de outros produtos aproveitáveis e indispensáveis: oxigênio, ar liquido, gazes etc. O ácido cloridrico tem suas bases na soda e a sua fabricação também envolve uma série de outros produtos de amplo emprêgo na indústria, como hidrogênio, sulfato de sódio etc.

As indústrias químicas e mecânicas de base originam uma imensa quantidade de transformações, matérias-primas e produtos que são a fonte de numerosas utilidades da vida moderna.

Enfim, as indústrias mecânicas e elétricas pesadas são as últimas que se montam num país em curso de industrialização. Exigem capitais vultosos e técnica apurada. Volta Redonda já fabrica peças de $100 \mathrm{t}$. Prensa hidráultica de $2.000 \mathrm{~T}$. já funciona em São Paulo. A indústria mecânica pesada está cam nhando bem no país, não se podendo dizer o mesmo da indústria pesada elétrica. Nada sabemos das atividades das firmas Brown Bovery e Siemens Schuckert em S. Paulo.

Assim pois, em uma Politica de Desenvolvimento, não se pode deixar de atender ao problema de infra-estrutura fundamental da economia nacional.

\section{0 - DESENVOLVIMENTO E ECONOMIA}

O exame met:culoso numa conjuntura econômica importa na pesquisa e análise dos processos de criação dos montantes da produção referentes a bens e serviços, a sua estrutura e os processos de formação do Produto e a expressão em têrmos monetários. A análise possibilitaria o reconhecimento dos desequilibrios, tanto estruturais como conjunturais, firmando a decisão e o equacionamento das ações visando o acréscimo do produto em caráter extensivo e aquêle que seria provocado pelo melhor aproveitamento dos fatôres de produção. São da ordem de três categorias o campo que prende a atenção do economista: a produção, a renda e o consumo. 
Na Produção teríamos que considerar a prevenção do desperdício estabelecendo a racionalização do emprègo dos fatôres visando:
a) seleção
b) combinação
c) ampliação
d) aglutinação

E o aumento da produtividade (Fortalecer o Potencial) e acrescentando outros valores ao Poder, encetando ações relativas a:
a) instrução
b) aquisição
c) manêjo
d) manutenção

No mesmo passo seriam removidos os pontos de estrangulamento em tôdas as operações que possam dar lugar à formação de um resultado final, bem ao serviço. Na indústria, a operação começaria na produção ou extração da matéria-prima, beneficiamento, comercialização, transportes, etc., até chegar às mãos do consumidor .

A transferência e importação de fatôres de produção na estratégia de sua mobilização e de seu uso.

O contrôle cu:dadoso da exportação dos fatôres de produção. Enfim, a produtividade levando a uma seleção dos fatôres ocupados e os dos bens produzidos, conduzindo a uma melhoria e aperfeiçoamento de equipamentos, mão-de-obra e organização do trabalho na sua máxima eficiência.

$\mathrm{Na}$ Renda, conseguir estimular a popupança, para dispor de maiores investimentos e:

a) seleção dos investimentos, pela natureza, localização e melhor aplicação de recursos;

b) contenção do processo inflacionário, pela politica de crédito e fiscal, impostos, relativo equilibrio orçamentário e disciplinação da Politica financeira;

c) estímulo à capitalização, máxima para reinvestimentos;

d) despertar confiança ao capital internacional para concorrer igualmente com o esfôrço de capitalização e investimentos nacionais;

e) essencialidade, prioridade, hierarquização, sugestões para invest mentos seletivos no plano geral de desenvolvimento; 
f) regularização econômico-financeira das emprêsas de economia mista;

g) supressão gradativa das subvenções aos empreendimentos que não apresentem reais fundamentos econômicos indiretos;

h) fiscalização e contrôle dos empréstimos e financiamentos a entidades oficiais, tendo representante na administração como fazem as agências internacionais de financiamentos (Estados e Municipios).

No consumo, atender a pressões impostas pela taxa demográfica, defendendo os níveis de consumo "per capita". Trataria da flexibilidade dos suprimentos, da adequação dos niveis e de acompanhar ou persuadir novos hábitos mais consentâneos com a análise levada a efeito na conjuntura e decorrente de um exame de situação. Na indústria de alimentação, por exemplo, ficaria bem mais simplificado o problema de abastecimento e prêço, e, especificamente, o aproveitamento racional da produção, quando a matéria-prima se localiza distante dos grandes campos de consumo.

$E^{\prime}$ muito difícil no pais estabelecer uma exatidão rigorosa em qualquer planejamento econômico. Por variados motivos fogem das estatísticas oficiais um sensivel volume de bens consumidos ou marginais a qualquer processo de fiscalização e contrôle. Quase tôda a produção industrial, realmente formando dentro de uma gama de produtos gozando evidente monopólio estatal e em benefício de certos grupos econômicos, foge de contrôles fiscais e estatísticos. Assim, pois, tanto pelo fato acima mencionado como pela tradicional forma de economias circulares e mesmo fechadas, grande parte da produção e do consumo não figura nas estatisticas oficiais. Decorrendo disto, vemos a baixa produção e consumo de manteiga, proteínas animais, produtos agrícolas, açucar, dôces, etc.

Com bastante convicção estamos inclinados a aceitar a tese de que o quadro sombrio brasileiro que conhecemos e expomos ao mundo acêrca de subnutrição, baixo nivel de produção, estacionamento ou baixa de nivel de vida, está equivocado em cêrca de $40 \%$.

As distorções da atividade econômica brasileira sob aspecto conjuntural, afirmando dentro de uma forte dinâmica o seu caráter pioneiro e aventureiro, não é melhor nem pior do que o quadro histórico verificado em quase tôdas as Nações mais desenvolvidas de hoje. Estas Nações e a Humanidade muito deveram aos aventureiros. Resguardados os graus naturais, tôda a atividade econômica se ressente de riscos maiores ou menores. Os grandes monopólios semi-oficiais sempre existiram. Nas insipiências educacionais, em pontos históricos considerados, sempre se serviram os homens públicos das atividades econômicas acobertadas pelo 
Estado para se enriquecerem. Acreditamos, pois, que o Brasil "sofre" a sua história. Foi o "sofrimento" aventureiro da história da corrida do petróleo nos Estados Unidos que contribuiu, em boa parcela, para a grandeza daquela Nação.

\section{0 - INTEGRAÇÃO DO PROCESSO DE DESENVOLVIMENTO}

O Produto Nacional Liquido, tomado como referência, é indice prático e significativo, na base "per capita", para diagnosticar o crescimento, quando há aumento. E' preciso ressaltar que o Produto, e não a Renda, indica crescimento. No cálculo desta entram as relações de trocas que podem resultar de melhorias ocorridas no setor externo. Estas melhorias podem não refletir crescimento na resultante de combinação dos fatôres de produção no campo territorial. O aumento do Produto Interno Liquido, real, documentando um desenvolvimento, só se consegue com inovações, transformações e modificações continuas na estrutura econômica. O fator mais importante desta mobilidade é a Tecnologia, Em salutar entrosamento, combinam-se a ciência aplicada, a técnica e a organização. Duas condições sociais importantes devem estar em cogitação para manter "tècnicamente" um Grau de Desenvolvimento Nacional: 1 - grupos sociais dinâmicos que tenham à sua disposição um quadro institucional continuo e politicamente planejado de pesquisas científicas e técnicas, de modo a permitir um aperfeiçoamento e uma atualização de novas técnicas e métodos de organização; e, visando incentivar "novas frentes" de atividades produtivas, favorecendo, em conseqüência, a formação de capital; 2 - disposição e determinação popular de subtrair ao consumo uma parcela ponderável de sua renda de modo a manter alta a taxa de investimentos, concorrendo assim para ampliar a capacidade dos fatôres de produção.

A combinação fundamental para um desenvolvimento econômico é quanto ao progresso tecnológico e a acumulação de capitais. Assim, pois, é preciso "descobrir" as necessidades tecnológicas, ter $\cap$ plano preestabelecido para atendê-las e saber como levar os empresários a aplicar as inovações, as transformações e as evoluções do processo tecnológico. Quanto à acumulação de capitais, tanto exige a predisposição social, atitude ou caráter propenso à poupança como uma Política adequada para conseguir a captação de capitais e a adequação conjuntural conveniente nos investimentos setoriais. Para se chegar a esta concepção de integração será preciso um trabalho gigantesco de pesquisas, perquirições, informações, a partir de setores amplos e caminhando em desdobramentos periféricos e particularizações, girando sempre em tôrno da origem e da formação de bens e serviços, das intercor- 
relações, das relações, dos fatos sociais e das características de evolução, para que sejam reconhecidos os pontos fracos da formação do produto.

E' da coleta cuidadosa de tais elementos que resulta aquela integração sintética de que falamos. O estudo analitico decorre da disponibilidade das estatísticas e informações e das possibilidades de ir da periferia, dos fenômenos parciais, das amostragens, dos dados, e dos fatos repetidos, levando a que se possa caminhar na concentração e ao mesmo tempo na amplitude do raciocínio, com certa segurança para que seja desvendado o todo, o "universo" econômico. E' dêste universo econômico que devem partir os estudos conjugados para que seja determinada a Política do Desenvolvimento que é a fase suprema da integração. O curioso é que as dificuldades, deformações, anomalias, tropeços e irregu.laridades das diversas fases e operações da formação dos bens e serviços e sua influência na constituição do "produto", tomam inclusive denominações características das tendências individuais e profissionais do pesquisador. Assim, o economista encontra o "estrangulamento"; o analista e o programista, "o ponto crítico"; na Segurança Nacional encontramos "a pressão ou obstrução" e o sociólogo "a fator negativo". O econom:sta mostra suavemente a condição técnica a ser solicitada para remover o "estrangulamento"; o analista e o programista não estabelecem maior classificação para o assunto deixando o arbitrio de decisão a outrem; a Segurança Nacional que deve "determinar" sôbre a técnica ou pela técnica classifica como "pressão ou obstrução" que deve ser vencida. Impõe pois, com mais veemência a ação do Poder. O sociólogo "constata" o "ponto negativo".

$\mathrm{Na}$ Segurança Nacional, no seu realismo definido, encontramos a decisão e o imperativo da determinação de ajustar. E' pois, a autoridade na legitimidade de seu poder que age vencendo "obstáculos e pressões", máxime, quando se encontram acessiveis na qualidade e na quantidade (valor) das possibilidades do Poder.

\section{1 - O Estudo Setorial}

Não podemos dar a amplitude de um estudo setorial, em todos os seus desdobramentos, particularidades, fatôres, etc., em um espaço de tempo tão limitado. Contudo, sendo a primeira fase de um caminho divergente longo e múltiplo, com uma série de ramificações e de cujo retôrno conclusivo resultará a visão e a análise do "universo" econômico, fundamento das Diretrizes Politicas, é preciso uma exposição sintética. Por outro lado, será 
a mesma trilha a ser seguida nas linhas da programação, onde cncontramos o Planejamento e os planos. E' o trabalho de diagnóstico, com o reconhecimento dos sintomas e a pesquisa etiológica que afirmará e firmará a decisão da terapêutica, com a assistência permanente e as revisões indispensáveis; a biologia social muito se assemelha ao organismo humano. Em verdade existe sòmente uma biologia - a social e a individual, intimamente integradas.

"O conhec'mento efetivo da situação dos diferentes setores produtivos ou, pelo menos, daqueles considerados de maior importância, é condição essencial para fixar-se corretamente as metas de produção e orientar-se adequadamente após investimentos. $\mathrm{E}^{\prime}$ fácil compreender-se, portanto, a importância dos estudos setoriais para programação econômica", escreveu José Pelúcio Ferreira, Chefe da Divisão de Estudos Setoriais do BNDE. Alinhou o mencionado autor alguns itens de investigações para focalizar os aspectos relevantes de um setor ou setores no programa de investimentos que são os seguintes:

a) Caracteristicas históricas do seu desenvolvimento. Responsabilidade dos agentes público e privado, em sua evolução. Papel e contribuição de fatôres institucionais e econômicos:

b) Posição no quadro geral de desenvolvimento da economia nacional;

c) Financiamento: origem e processos de captação de recursos para seu desenvolvimento;

d) Estrutura e formas de organização do setor. Características dominantes das unidades componentes.

e) Estrutura e composição do estoque de capital. Características técnicas;

f) Utilização do estoque de capital;

g) Fôrça de trabalho. Capacitação técnica. Produtividade;

h) Outros fatôres de produção; características; e

i) Posição do setor no mercado nacional.

(Revista do BNDE-1 - Jan.-março - 1964)

Cada setor possui evidentemente seus desdobramentos e suas categorias a serem investigadas dentro do mesmo espírito de conseguir a integração setorial e seu papel próprio na Política de Desenvolvimento, ao formar nos grupos dos setores que englobam tôdas as atividades da dinâmica social. 


\section{0 - Regimes Politicos e Desenvolvimento}

Qualquer que seja o regime politico considerado não pode sofrer alterações profundas a doutrina e a técnica econômicas. A substância da diferenciação nós vamos encontrá-la na "imposição" de certas condições que favorecem a capitalização e a prioridade essencial que se dá ao sentido coletivo dirigido e forçado de consumo, nos sistemas totalitários e mesmo ditaduras. Tôda autoridade exerce um poder de coação. Contudo, no regime representativo popular da vontade livremente expressa pelo voto, a fôrça da autoridade decorre de uma coação consentida e regulada pela vontade de uma maioria através da garantia das leis. Estas disciplinam as relações entre o Estado, seu govêrno e o povo. Êste por delegação de seus legítimos representantes, es tampa nas leis a forma e as condições em que se sujeita a ser coagido. Verifica-se logo que o Estado foi uma criação juridica e o govêrno uma forma de autoridade, ambas destinadas a servir ao povo. Nos governos autoritários e especificamente totalitá rios, o cidadão é obrigado a servir ao Estado como fim e na democracia é o Estado que deve servir aos cidadãos.

Dentro, pois, do contexto da evolução politica, o govêrno autoritário ou totalitário é um retrocesso ao Poder do Estado na era feudal que servia apenas aos interêsses das oligarquias dominantes. Por outro lado, nos acontecimentos históricos que nos séculos XVIII e XIX reforçaram a tendência do povo de ser a fonte autêntica de poder politico, foram firmados fatos marcantes de uma evolução e renovação sociais, com o fortalecimento de uma classe produtora de bens: a burguezia. Em realidade, a escola liberal econômica firmourse no século XVIII, na França, com os fisiocratas. Tomou amplitude e adeptos com Adam Smith, Malthus, Ricardo e Stuart-Mill, na Inglaterra e Say, na França. A idéia dos fisiocratas partia de idéias pré-industriais e enfatizavam as atividades agrícolas. A escola clássica foi Adam Smith (17231790). Era o princípio da inteira liberdade individual de iniciativa, dando ao autor clássico citado a oportunidade de proclamar a eficácia da divisão de trabalho que tem a "virtude de aumentar a produtividade total de maneira maravilhosa". Contudo, na sua própria escola, apareceram as considerações pessimistas de Malthus e Ricardo (1766 1836) e (1772-1823) respectivamente. O primeiro dizia que a população tenderia a aumentar mais depressa do que as subsistências necessárias a sua manutenção (leis de Malthus). Ricardo acreditava que os proprietários do solo tenderiam a enriquecer-se cada vez mais em detrimento das outras classes da nação (leis de Ricardo). Os salários e os lucros ten- 
deriam a aumentar, às expensas uns dos outros; os lucros baixariam e a indústria se estagnaria. Era o futuro desolador previsto pela ciência econômica da época. Ela é, verdadeiramente, uma ciência da desgraça, escrevia Carlyle. Foi com Stuart-Mill, apesax de enaltecer o individualismo e a inteira liberdade da iniciativa privada, sem freios, sem disciplina, sem contrôle e sem fiscalização ao sabor da atitude expectante do Estado e a intervenção de Augusto Comte e o Saint-Simonismo, que se iniciou a ação do Estado na direção das atividades econômicas. U'a multidão de opositores surgiu a combater as idéias liberais, sendo de ressaltar aquelas de Wagner, com a relatividade e a mobilidade do meio social se contrapondo ao duplo caráter de permanência e universidade da escola econômica clássica. Dizia êle: "A propriedade privada e o salariado nem sempre existiram e nem sempre existirão sob a forma que hoje conhecemos, pois a lei por excelência é a da evolução". As medidas legislativas devem, pois, também, variar no tempo e no espaço, para ajustar-se às necessidades de cada povo, dizia Wagner. Estava prevista a Democra cia Social no século seguinte.

Contudo, a voz mais violenta contra o sistema econômico liberal partiu de Carl Marx que com seu companheiro Engels foi justamente refugiar-se na pátria do liberalismo econômico, a In glaterra, em meiados do Século XIX. Estava tão forte o liberalismo, que o Estado liberal se dava ao desplante de acolher o seu mais ferrenho inimigo, escorraçado do continente.

A economia liberal da Inglaterra era excepcionalmente auxiliada pelo mundo inteiro. Do Brasil, através de seus tratados com Portugal e. especificamente, o tratado de Methuen, de 1703, haviam sido drenados um milhão de quilos de ouro ou um têrço da quantidade mundial existente. Mas, como o mercado se expandia, em virtude de terem-se combinado as seis condições citadas por Ellul em sua obra La Tecnologia au l'enjeu do $X X^{e}$ Siècle, construiu o liberalismo a Tecnologia. Com esta tomou nôvo sentido a ciência econômica na direção do Desenvolvimento e houve possibiliddae de estruturar as bases do Estado Democrático. Felizmente, para a Humanidade, foram mais ou menos concomitantes as declarações dos direitos da pessoa humana, de Voltaire, em 1781, e a Revolução Francesa que deslocou a nobreza feudal dos favores e privilégios da posse e gôzo de certos bens e serviços.

Contudo, a Tecnologia serviu durante muitos anos e ainda serve para favorere a certo grupo de nações que gozaram dos benefícios do liberalismo e, em conseqüência, da aquisição dos va- 
lores tecnológicos. Ainda vigorou muito intensamente o liberalismo nas relações internacionais, mas, com vantagens inegáveiss para os que possuiam a Tecnologia.

No entanto, hoje, apesar de tudo, estão todos compreendendo o exato significado da filosofia democrática de vida. Por razões que não nos importam discutir, já se nota certa tendência de igualdade de nações, grandes e pequenas, de acôrdo com as teses ardorosamente definidas por Ruy Barbosa na Côrte de Haya, em 1907.

O Estado Moderno Democrático tomou a seu cargo uma série de medidas e iniciativas tendentes a "humanizar" a economia. A medida que cresceu o organismo econômico em profundidade, extensão e complexidade, pôs-se logo a necessidade de regulamentar melhor a sua atividade. A expansão dos transportes e comunicações, o amplo emprêgo da energia, a ação importante da técnica de propaganda, o gigantismo de grandes emprêsas econômicas, a importância da educação no setor da produtividade, o aumento populacional etc., trouxeram a mais ampla responsabilidade do Estado na regulamentação, na fiscalização, no contrôle, na suplementação e no atendimento dos interêsses e necessidades coletivos. O Estado tem obrigação de estabelecer um clima favorável de progresso e de desenvolvimento.

Assim sendo, tem que conseguir os meios necessários e indispensáveis para levantar o quadro universal da economia e fundamentar a Política Nacional. Atuando assim, não poderá deixar de conciliar a necessidade de aumentar cada vez mais o grau de bem-estar da nação e ao mesmo tempo proporcionar a máxima garantia. No primeiro caso, cuidará de uma Politica de Desenvolvimento e no segundo, da Política de Segurança Nacional.

A Economia que foi a ciência da riqueza de alguns e a ciência da miséria e da desgraça, segundo Carlyle, é hoje a ciência da prosperidade dos povos, do progresso, da evolução e da paz social. Na função de governar, que é a Arte e Técnica de equacionar problemas, ela é sustentáculo do Planejamento, base fundamental da racionalização de ações, possibilitando, determinando, provendo, prevendo, controlando e fiscalizando. E' na conjugação de Economia e Planejamento que nascem as Diretrizes para o Desenvolvimento dos povos, cada vez mais exigentes na sua demanda de maior bem-estar.

Nas mãos da Economia, da Ciência e da Tecnologia e do Planejamento está o destino das multidões que lotarão o planeta nos anos vindouros. 


\section{ANEXO 1 \\ BRASIL}

IMPORTAÇÃO DE MINERAIS E PETRÓl.EO

1963

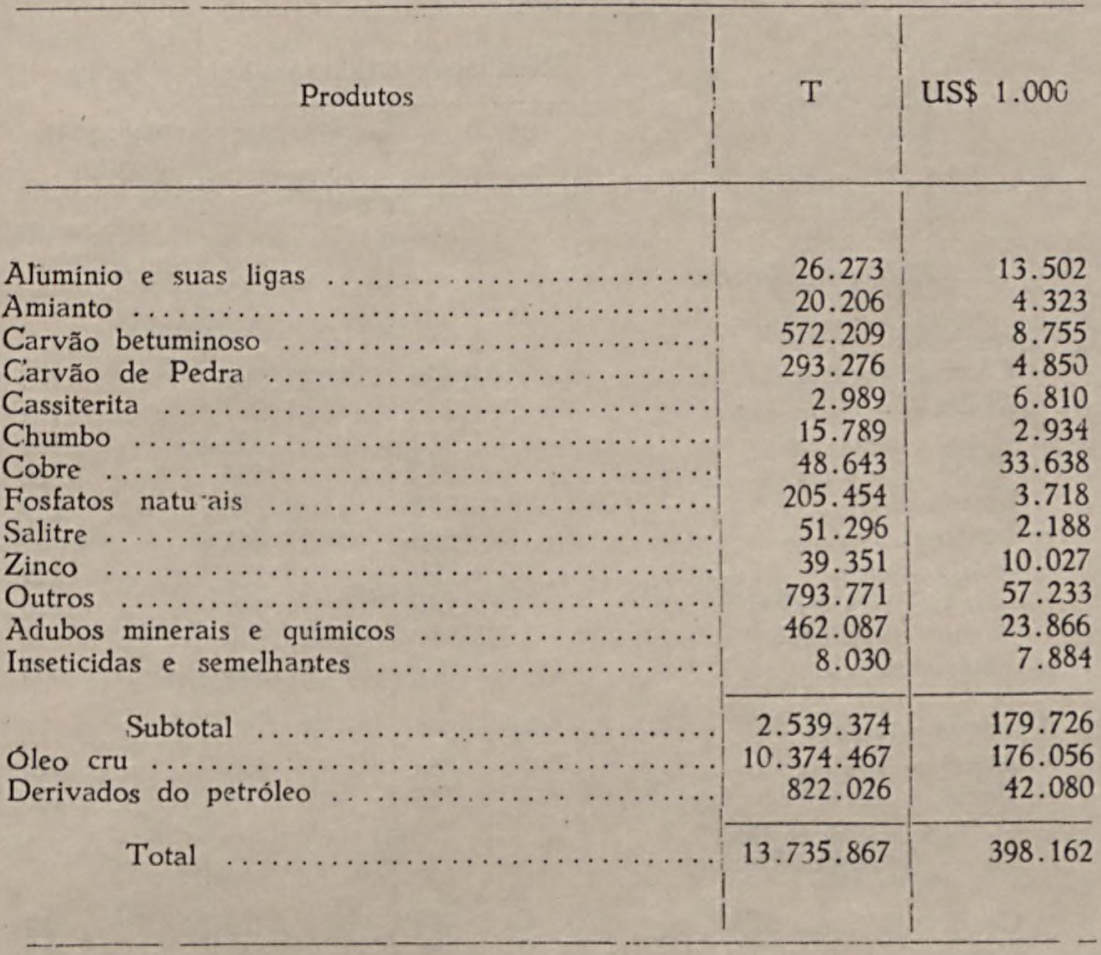

IMPORTAÇÃO DE ALIMENTOS

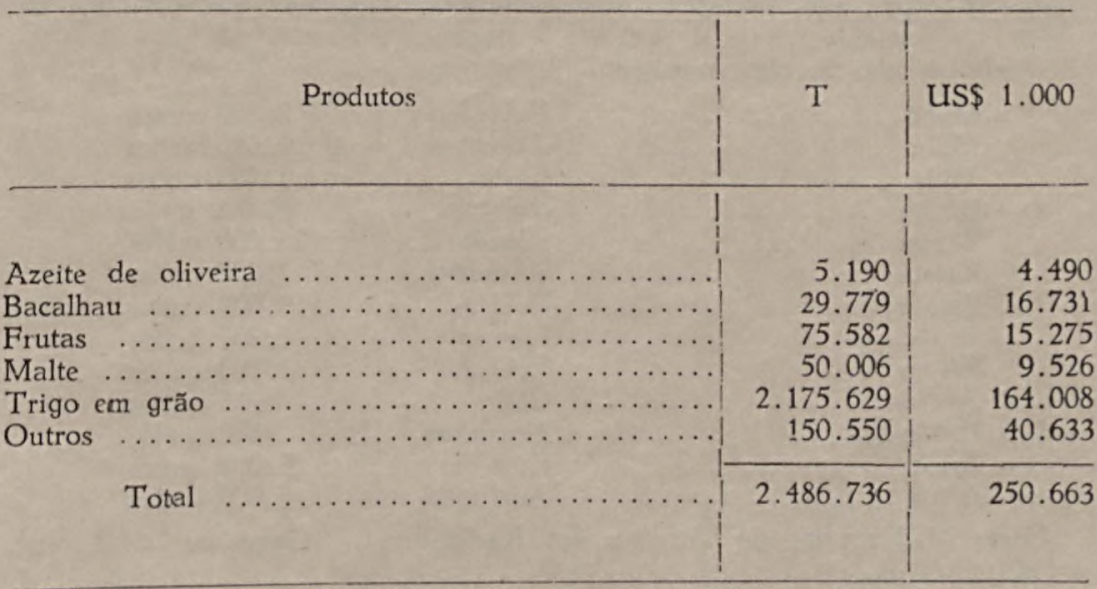


ANEXO 2

\section{PRODUTIVIDADE AGRICOLA}

EVOLUÇÃO DO RENDIMENTO MÉD.O FOR UNIDADE ÁREA PLANTADA

$$
1947-1961
$$

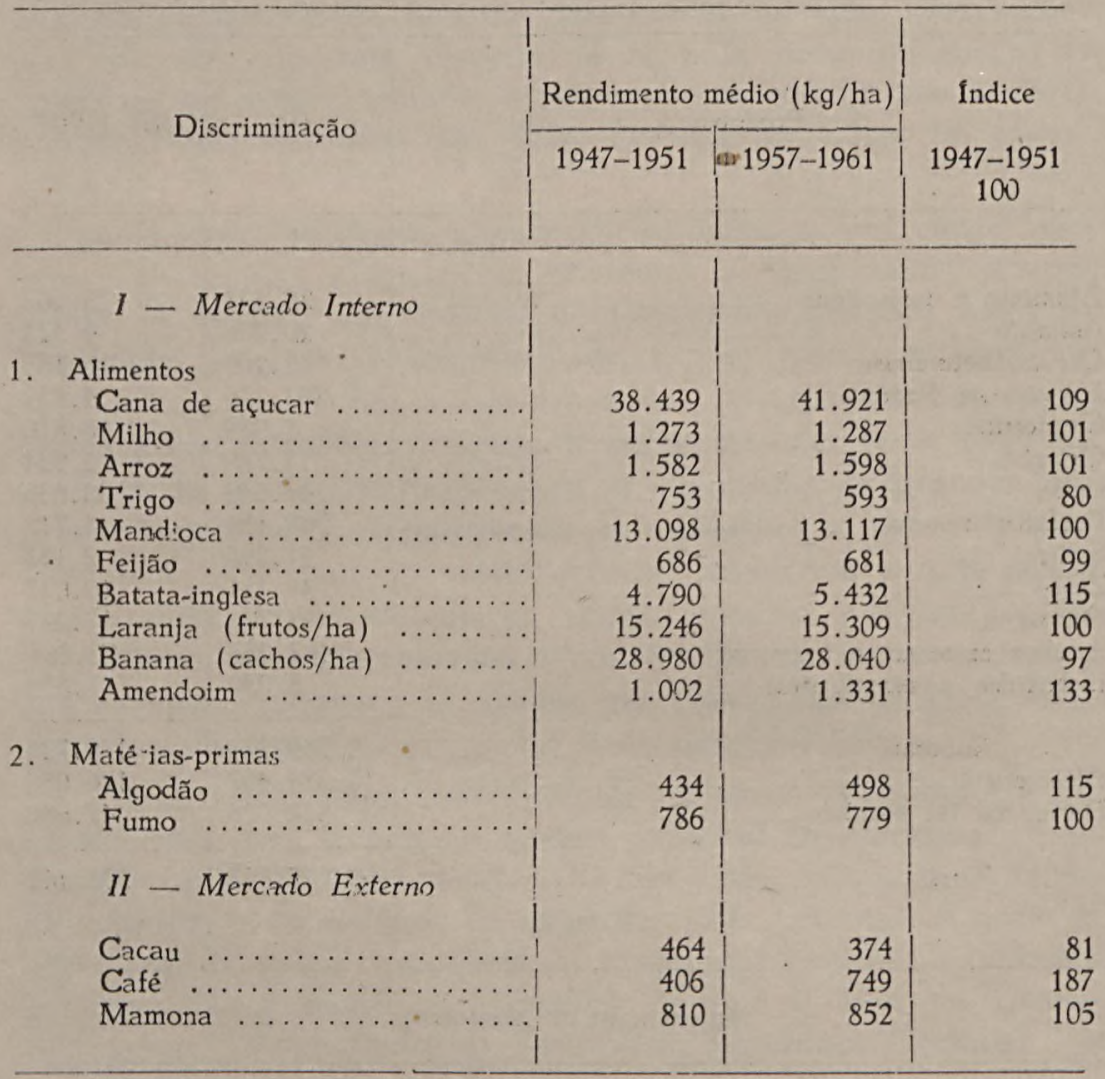

P.odutividade em alguns paises:

\begin{tabular}{|c|c|c|c|}
\hline Milho & & E.U.A. & 2.200 quilos \\
\hline Milho & & Argentina & 1.690 quilos \\
\hline Milho & & Chile & 1.795 quilos \\
\hline Batata & & Holanda & 29.000 quilos \\
\hline Batata & $\ldots$ & Irlanda & 24.000 quilos \\
\hline Batata & $\ldots \ldots \ldots \ldots$ & Argentina & 7.000 quilos \\
\hline Batata & & E.Ü.A. & 19.000 quilos \\
\hline Feijão & $\cdots$ & Libano & 1.300 quilos \\
\hline Feijão & & E.U.A. & 1.100 quilos \\
\hline Feijão & $\ldots$ & Chile & 915 quilos \\
\hline Feijão & & Argentina & 880 quilos \\
\hline Arroz & & Espanha & 5.000 quilos \\
\hline Arroz & & Austrália & 5.000 quilos \\
\hline
\end{tabular}

Fonte: 1 Encontro de Técnicos em Agricultura - Campinas - Agôsto -1964 . 
ANEXO 3

\section{CONTRIBUIÇÃO DA TECCNICA-ORGANIZAÇÃO NA PRODUÇÃO INDUSTRIAL}

$$
\text { (Professor Aukrust - periodo - } 1900-1955 \text { ) }
$$

Notuega

Aumento de capital ............... 5,6\% - anual

Aumento de trabalho ............... $0,6 \%$ - anual

Taxa de progresso econômico ........ 3,4\% - anual

Distributção da taxa de progresso

Contribuição do capital ............ 1,12\% - anual

Contribuição do trabalho ............ $0,48 \%$ - anual

Contribuição técnica e organização $\ldots . . \quad 1,81 \%$ - anual

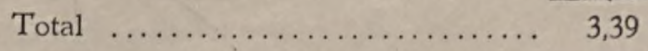

Inglaterra - 1948 - 1954 - (Comissão econômica)

Incremento do produto industrial - M£ 1948 -

Contribuição do trabalho $\ldots \ldots \ldots \ldots \ldots$ £ 314,8

Contribuição do capital ............ $\quad £ 311,9$

Contribuição técnica-organização $\ldots \ldots \ldots$ £ 553,6

E. U. A. $-1900-1949$ - (Prof. Robert Solow - MIT)

Contribuição do capital $\ldots \ldots \ldots \ldots \ldots$ US $\$ 0,35 \%$ anual

Contribuição do trabalho ............ US $\$ 0,65 \%$ anual

Contribuição técnica-organização ....... US $\$ 1,5 \%$ anual

Observação importante. - Para o progresso e o desenvolvimento teve influência destacada a técnica-organização sôbre capital-trabalho juntos. Segundo - Prof. Solow, uão havendo constante acréscimo de novas técnicas na indústria norte americana, em duas décadas a "renda per capita" descerá a quase "0". 
ANEXO 4

E.U.A.

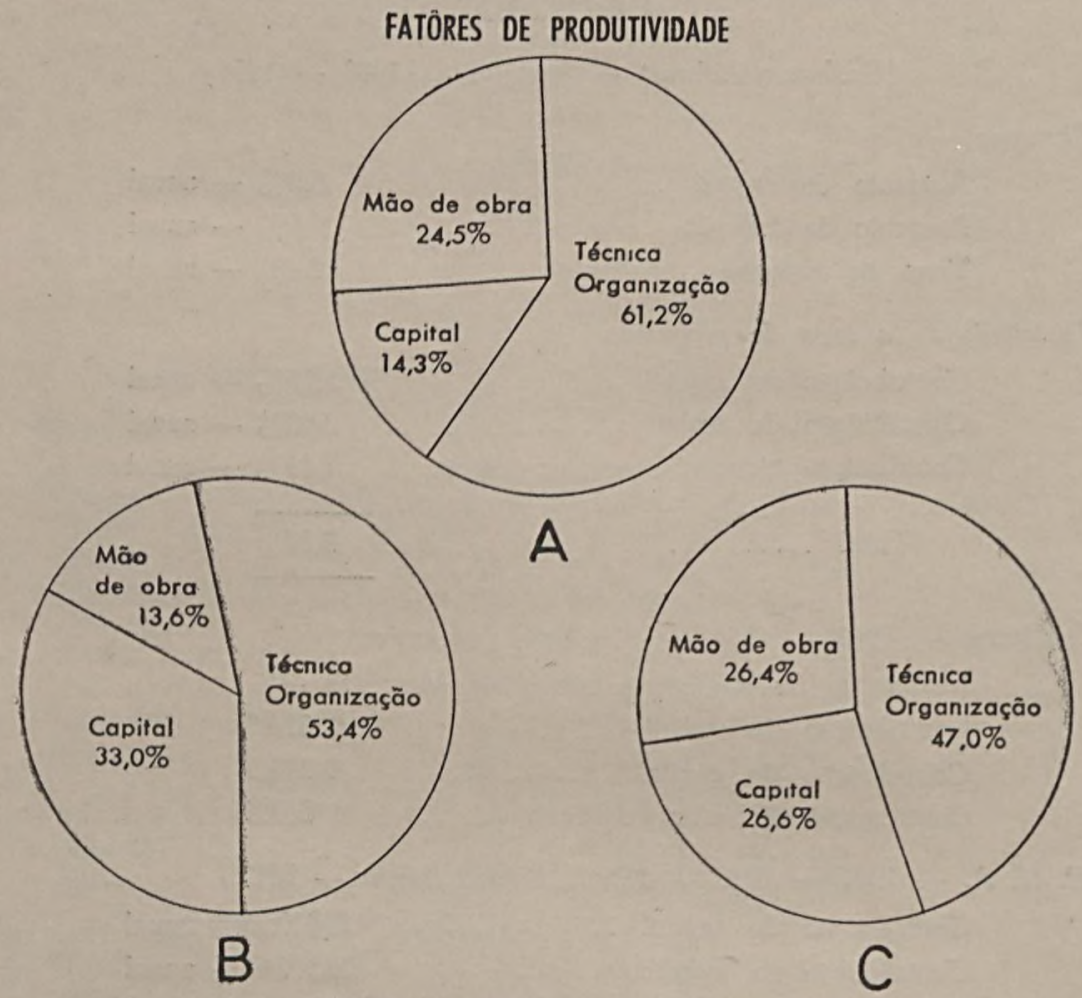

Fontes - Prof. Aukrust - Noruega. Prof. Robert Solow - MIT. E.U.A. Inglaterra - Comissão de economistas - José de Almeida Rios - Da Conferência $\ll$ Desenvolvimento e Fortalecimento do Potencial Nacional. ADESG - 1964 
ANEXO 5

\section{INFLUENCIA DA TÉCNICA - ORGANIZAÇAO NA PRODUÇÅO}

O Professor Arkrust, da Noruega, fêz pesquisas de 1900 a 1950 para verificar os fatôres de produção e a influência de cada um na formação do p:oduto final. Para cada $1 \%$ de capital houve 0,20 de aumento do produto. Para cada $1 \%$ de aumento de mão-de-obra, houve 0,76 de aumento do produto.

Para um aumento anual de capital de 5,6\% $\times 0,20=1,12$

Para, um aumento de mão-de-obra de $0,6 \times 0,76=0,46$

A técnica e organização contribuiu com $\ldots \quad=1,81$

A taxa econômica de crescimento foi de $\ldots=3,4$

O Professor Robert Solw, nos EE.UU. fez as mesmas pesquisas chegando a resultados aproximados, assim:

O capital contribuiu com $\ldots \ldots \ldots \ldots \ldots \ldots \ldots ., 0,35$

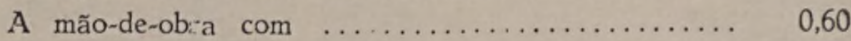

A Técnica e Organização .................. 1,50

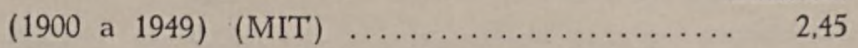

$\mathrm{Na}$ Inglaterra, uma Comissão de Economistas fêz o mesmo estudo de 1948 a 1954:

O capital contribuiu com $\ldots \ldots \ldots \ldots \ldots \ldots \ldots \ldots \ldots \ldots \ldots$

A mão-de-obra com $\ldots \ldots \ldots \ldots \ldots \ldots \ldots \ldots \ldots \ldots \ldots \ldots \ldots \ldots$

A Técnica-Organização $\ldots \ldots \ldots \ldots \ldots \ldots \ldots \ldots \ldots \ldots \ldots \ldots \ldots$ 
ANEXO 6

BRASIL

A QUALIFICAÇÃO POPULACIONAL E O PROGRESSO ECONOOMICO

$$
\begin{aligned}
& \text { Renda "per capita" }-(1960)-\operatorname{Cr} \$ 1.000 \\
& \text { Brasil }=27,3
\end{aligned}
$$

Estados

Percentagem de analfabetos - população maior de 5 anos

\begin{tabular}{|c|c|c|}
\hline Amazonas ... & 18,1 & $63 \%$ \\
\hline Pará $\quad \ldots \ldots \ldots \ldots \ldots \ldots \ldots \ldots \ldots \ldots$ & 15,2 & $58 \%$ \\
\hline Maranhão...$\ldots \ldots \ldots \ldots \ldots \ldots \ldots$ & 9,1 & $78 \%$ \\
\hline Piaui $\ldots \ldots \ldots \ldots \ldots \ldots \ldots \ldots \ldots \ldots$ & 7,6 & $78 \%$ \\
\hline Ceará $\ldots \ldots \ldots \ldots \ldots \ldots \ldots \ldots \ldots \ldots$ & 11,9 & $73 \%$ \\
\hline Paraiba $\ldots \ldots \ldots \ldots \ldots \ldots \ldots \ldots \ldots \ldots$ & 14,3 & $75 \%$ \\
\hline Rio Grande do Note $\ldots \ldots \ldots \ldots$. & 15,0 & $72 \%$ \\
\hline Pernambuco $\ldots \ldots \ldots \ldots \ldots \ldots \ldots$ & 15,9 & $73 \%$ \\
\hline Alagoas $\ldots \ldots \ldots \ldots \ldots \ldots \ldots$ & 13,5 & $80 \%$ \\
\hline Sergipe $\ldots \ldots \ldots \ldots \ldots \ldots \ldots \ldots$ & 14,5 & $71 \%$ \\
\hline Bahia $\ldots \ldots \ldots \ldots \ldots \ldots \ldots \ldots \ldots \ldots$ & 14,9 & $73 \%$ \\
\hline Minas Gerais $\ldots \ldots \ldots \ldots \ldots \ldots \ldots$ & 19,1 & $62 \%$ \\
\hline Espirito Santo $\ldots \ldots \ldots \ldots \ldots \ldots$ & 17,2 & $59 \%$ \\
\hline Rio de Janeiro $\ldots \ldots \ldots \ldots \ldots \ldots$ & 25,5 & $50 \%$ \\
\hline Guanabara $\ldots \ldots \ldots \ldots \ldots \ldots \ldots$ & 82,3 & $20 \%$ \\
\hline São Paulo $\ldots \ldots \ldots \ldots \ldots \ldots \ldots \ldots$ & 47,4 & $41 \%$ \\
\hline Paraná $\ldots \ldots \ldots \ldots \ldots \ldots \ldots \ldots \ldots \ldots \ldots$ & 29,9 & $54 \%$ \\
\hline 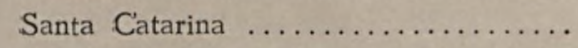 & 23,9 & $43 \%$ \\
\hline Rio Grande do Sul $\ldots \ldots \ldots \ldots \ldots \ldots$ & 32,1 & $41 \%$ \\
\hline Mato Grosso $\ldots \ldots \ldots \ldots \ldots \ldots \ldots$ & 21,0 & $56 \%$ \\
\hline Goiás $\ldots \ldots \ldots \ldots \ldots \ldots \ldots \ldots \ldots \ldots$ & 14,5 & $72 \%$ \\
\hline
\end{tabular}

(1950) 
ANEXO 7

\section{QUALIFICAÇÃO POPULACIONAL E PROGRESSO ECONOMMICO}
A RENDA SOCIAL PEI.A EDUCAÇÃO

Renda social gerada no periodo de vida útil pelas categorias de ensino (cruzeiros de 1959 - milhões):

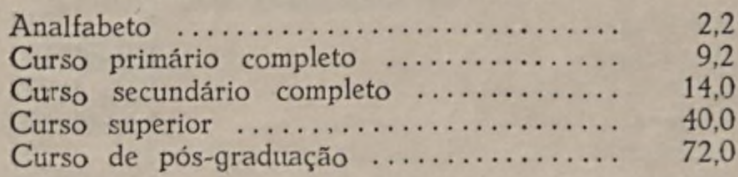

Salários recebidos no periodo de vida útil

Sem escolaridade .................. 1,4

Curso primário completo ............ 4,4

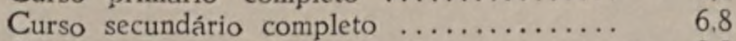

Curso superior completo $\ldots \ldots \ldots \ldots \ldots \ldots . \quad 9,8$

Cưso de pós-graduação $\ldots \ldots \ldots \ldots \ldots \ldots$ 11,7

Recuperação dos custos sociais e dos custos diretos

Curso elementar completo - custo social - 10 meses

Curso médio completo - custo social - 12 meses

Curso médio completo com salários-diretos -3 anos

Curso superior completo - custo social - 3 anos e 4 meses

Curso superior completo com salários-diretos - 3 anos

Curso pós-graduação - custo social - 1 ano

Curso pós graduação com salários-diretos -4 anos

Nota importante - No custo social entra a contribuição da sociedade e da falta da renda do trabalho.

Pesquisas e cálculo semelhante nos E. U. A.

\begin{tabular}{|c|c|c|c|}
\hline & & US\$ & Indice \\
\hline & Não escolarizados $\ldots \ldots \ldots \ldots \ldots \ldots$ & 58.000 & 100 \\
\hline 2) & 1-4 anos (escolaridade) ....... & 72.000 & 124 \\
\hline 3) & $5-7$ anos $\ldots \ldots \ldots \ldots \ldots \ldots$ & 93.000 & 160 \\
\hline 4) & 8 anos (ensino elementar) ....... & 116.000 & 200 \\
\hline 5) & 9-11 anos (curso médio) $\ldots . . .$. & 135.000 & 233 \\
\hline 6) & 12 anos (curso médio completo)... & 165.000 & 284 \\
\hline 7) & $13-15$ anos (curso superior) $\ldots \ldots$ & 190.000 & 328 \\
\hline 8) & 16 anos (curso superior completo) & 268.000 & 462 \\
\hline & Média ponderada $\ldots \ldots \ldots \ldots$ & 115.000 & 195 \\
\hline
\end{tabular}

Fontes: "Americal Sociological Review" jui - 1956 - pág. 307 - Slick and Müller. CAPES "Formação de Pessoal de Nivel Superior e Desenvolvimento Econômico - 1960. Seminário de Ensino Supe:ior, Chicago, 1960 janeiro. 


\section{ANEX) 8}

\section{PRODUTIVIDADE NA AGRICULTURA}

Em paises desenvolvidos é comum haver 200 agrônomos veterinários por 10.000 pessoas ocupadas na egricultura.

Número de técnico-agricola por número de estabelecimentos

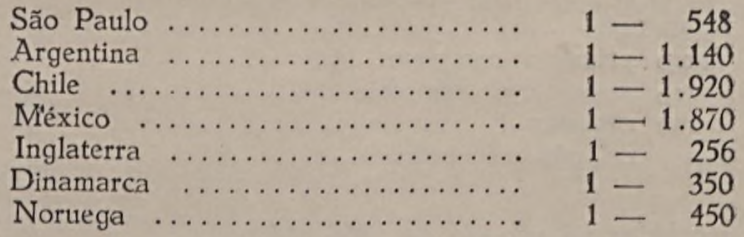

Aluguns Estados Norte-Americanos

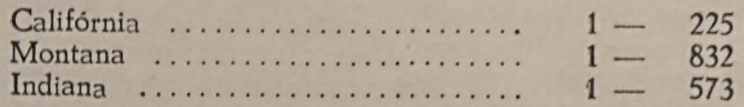

(Reunião dos tếcnicos agricolas - Campinas - SP. - Agôsto - 1964).

Relação entre nimero de trabalhadores agricolas e população

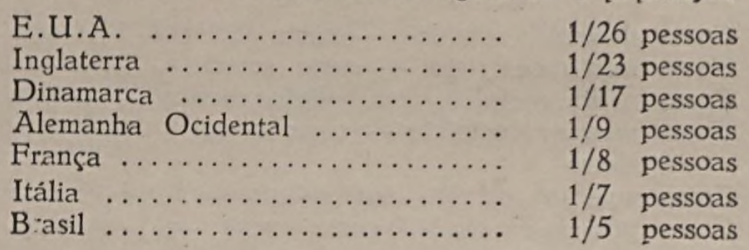

Populą̧áo total dependente da agricultura e área agricola cultivada por pessoas dependente da agricultura

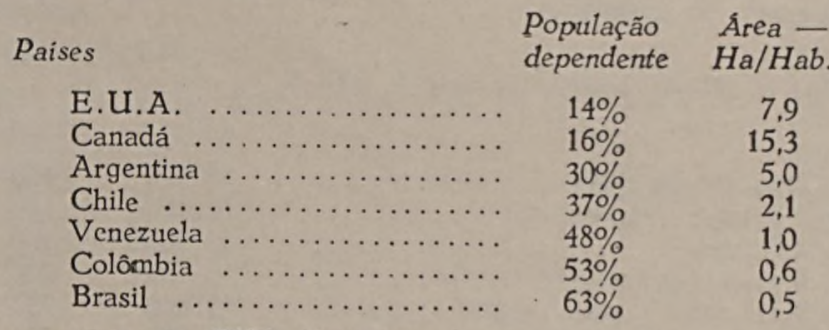

Documentário do CNE, Relatório. 
$\mathrm{SSN} / \mathrm{MEC}$

RENDA SOCIAL GERADA NO PERIODO DE VIDA ÚtIL PELAS CATEGORIAS DE ENSINO

\section{Cursos:}

pós-graduação

superior
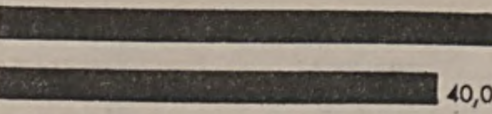

sec. completo

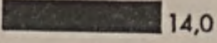

prim. completo

analfabeto

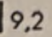

SALÁRIOS RECEBIDOS NO PERIODO DE VIDA ÚTH SEGUNDO O GRAU DE ESCOLARIDADE

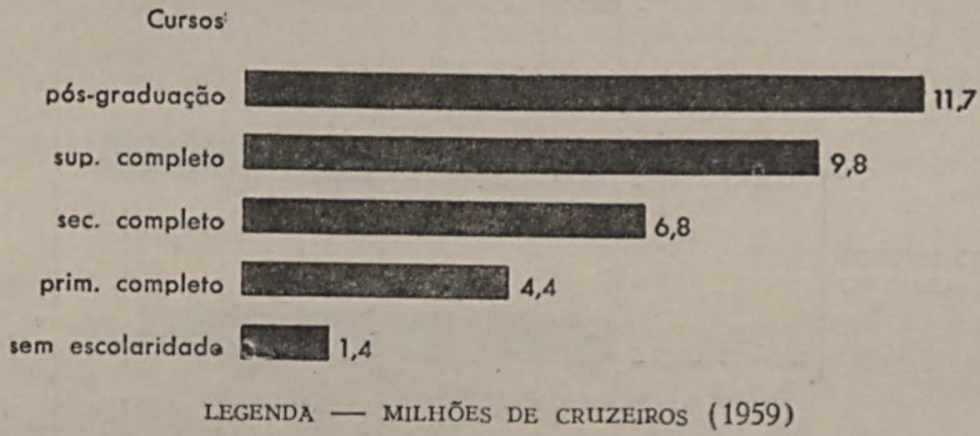

Fonte - CAPES - «Formação de Pessoal de Nivel Superior e Desenvolvimento Econômico» - 1960 
SSN/MEC

ANEXO 10

TEMPO DE RECUPERACÃ̃O DO CAPITAL INVESTIDO NA EDUCAÇ̄̃O ESCOLAR

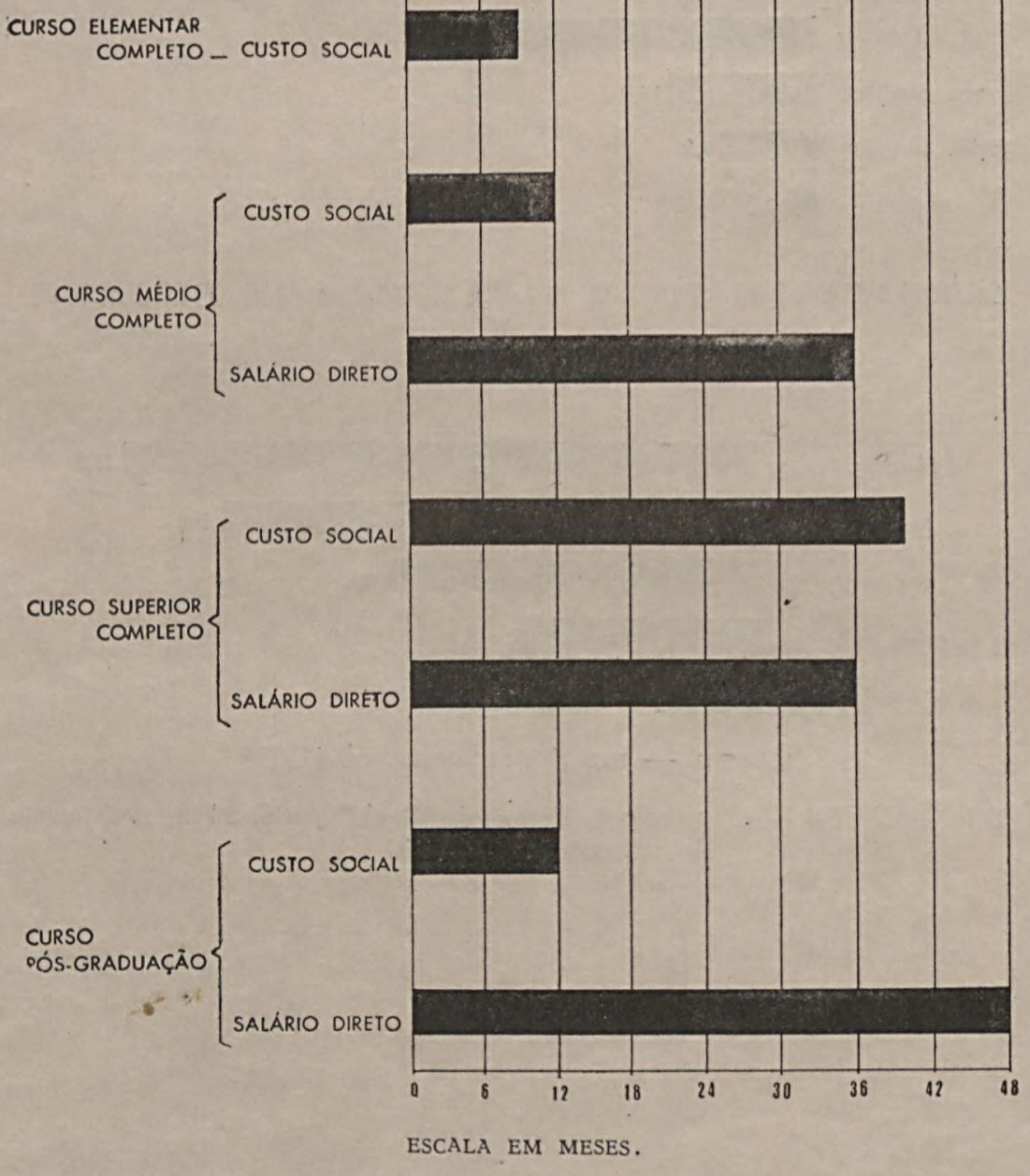

Fontes - «Americal Sociological Review» - Juin - 1956, pg. 307 - Slick $\mathcal{E}$ Müller. CAPES - «Formação de Pessoal de Nivel Superior e Desenvolvimento Econômico», 1960. Seminário do Ensino Superior, Chicago, jan. 1960. 